\title{
Evaluation of Some Heavy Metals in Wetland Soils of Uguru, Yobe State, Nigeria
}

\author{
${ }^{\text {A}}$ EGWU, GN; *2OKUNOLA, OJ; ${ }^{1}$ UGWOKE, KC \\ ${ }^{1}$ Department of Integrated Science, Federal College of Education, Zaria, Nigeria \\ ${ }^{* 2}$ Department of Applied Chemistry, Federal University Dutsin-ma, Katsina, Nigeria \\ *Corresponding Author Email: okunolaoj@gmail.com/egwugn@gmail.com
}

\begin{abstract}
Some physicochemical properties and concentrations of $\mathrm{Pb}, \mathrm{Fe}, \mathrm{Cd}$ and $\mathrm{Zn}$ in wetland soils of Uguru, Yobe State, Nigeria were evaluated at different locations in the study area using standard methods. Results (mean $\pm \mathrm{SD}$ ) for the soil physicochemical properties showed that $\mathrm{pH}$ ranged from $6.10-8.85$, electrical conductivity (EC) ranged from 0.060 to $0.875 \mathrm{mScm}^{-1}$, organic carbon (OC) ranged from $1.131-9.428 \mathrm{mg} / 100 \mathrm{~g}$, Exchangeable base ranged from $2.47-12.80 \mathrm{mg} / \mathrm{l}$ for $\mathrm{Ca}, 0.688-2.416 \mathrm{mg} / \mathrm{l}$ for $\mathrm{Na}, 0.100-3.285 \mathrm{mg} / \mathrm{l}$ for $\mathrm{K}$ and $0.316-0.849 \mathrm{mg} / \mathrm{l}$ for $\mathrm{Mg}$, total nitrogen $(\mathrm{TN})$ ranged from 0.070 to $0.140 \mathrm{mg} / \mathrm{l}$ and available phosphorus (AP) ranged from $1.131-9.428 \mathrm{mg} / 100 \mathrm{~g}$. The concentrations of $\mathrm{Pb}, \mathrm{Fe}, \mathrm{Cd}$ and $\mathrm{Zn}$ ranged $0.53-84.95 \mathrm{mg} / \mathrm{kg}$ for $\mathrm{Pb}, 1.95-29.90 \mathrm{mg} / \mathrm{kg}$ for $\mathrm{Fe}, 0.13-24.95 \mathrm{mg} / \mathrm{kg}$ for $\mathrm{Cd}$ and $1.63-24.95 \mathrm{mg} / \mathrm{kg}$ for $\mathrm{Zn}$. Generally, the profile of heavy metal followed this order: $\mathrm{Pb}>\mathrm{Zn}>$ $\mathrm{Fe}>\mathrm{Cd}$. $\mathrm{Pb}$. However, the levels of all metals presented with exception of $\mathrm{Cd}$ across the sites were found within the permissible levels recommended for agricultural soils. High concentrations of $\mathrm{Cd}$ in some of the sites suggested a possible contamination of the farmlands.
\end{abstract}

\section{DOI: https://dx.doi.org/10.4314/jasem.v22i6.24}

Copyright: Copyright $\odot 2018$ Egwu et al. This is an open access article distributed under the Creative Commons Attribution License (CCL), which permits unrestricted use, distribution, and reproduction in any medium, provided the original work is properly cited.

Dates: Received: 02 May 2018; Revised: 13 June: 2018; Accepted: 29 June 2018

Keywords: Wetland, Soils, Heavy Metals and Nguru

According to Ramsar (1994), wetland is defined as areas of marsh, fen, peatland, or water, whether natural or artificial, permanent ortemporary, with water that is static or flowing, fresh, brackish, or salt, including areas of marine water with depth of which at low tide does not exceed six meters. They are among the Earth's most productive ecosystem (Barbier et al., 1997).The life support systems that are inherent within the wetlands ecosystems can provide a wide range of valuable functions to society provided the primary users are incorporate in the management of the wetlands within the context of societal livelihoods and local institutions (Folke, 1991).The occurrence of wetland in Nigeria according to Okusami and Rust (1992) has been associated with three landform types, which are inland depression, alluvial plains, and coastal plains. They are used by peasant farmers in sub-Sahara Africa for agricultural production and water sources for domestic consumption as well as dump sites for urban domestic wastes (Binns et al., 2003; Mbabazi et al., 2010; Adelana et al., 2016).However, the introduction of harmful substances into the environment has been shown to have many adverse effects on human health, agricultural productivity and the natural ecosystems. Heavy metals pollution of the environment, even at low levels and the resulting long-term cumulative health effects are among the leading health concerns all over the world today. In wetlands, heavy metals exist mainly in water, in sediment and in plants and accumulate more easily in soils as a result of changes in natural environment and dominating influence of anthropogenic activities (Ita and Anwana, 2017; May and Edwards, 2001; Mitsch and Gosselink, 2000).

Also, in wetlands, soil, not only serves as source of essential nutrients for crops but also functions as sink for heavy metal pollutants. This ecological function of soil is most pronounced in wetlands (Ita and Anwana, 2017). Their distribution cause changes among the different compartments of each system. The accumulations of heavy metals in wetlands have deleterious effect on human health, as wetlands are the important sources of food and water for human beings. Therefore, as the importance and problems of wetlands in Nigeria cannot be over emphasized as it serve as important sources of food and water for human beings and also constitute health hazard due to 
heavy metal deposits. It is therefore pertinent to protect soil resources while studies are carried out on the levels of the heavy metals in the soils to ascertain their risk to human. Based on the importance of wetlands as describe in several literatures (Rafferty, 1994; Nwankwoala, 2012; Kar, 2013; Verones et al., 2013) coupled with paucity of data in literature on the concentration of heavy metals in soils in the wetlands of Nguru wetlands. Therefore, the objective of the study was to determine the levels of $\mathrm{Pb}, \mathrm{Fe}, \mathrm{Cd}$ and $\mathrm{Zn}$ and the soil physicochemical parameters as results of agricultural and other activities carried out within the lands.

\section{MATERIALS AND METHODS}

The Study Area: The Hadejia-Nguru Wetlands is a wide expanse of floodplain wetlands situated in the northeast Nigeria, the location lies in the Sudan Sahelianzone, which is the zone between the Sudanian Savanna in the south and the Sahel in the North. The wetland is found in Yobe state, located in the northern part of Nigeria, which include the Nguru Lake (Elegbede et al., 2014). The HadejiaNguru wetland is the first Nigeria wetland to be named as a Ramsar site (Ramsarm 1994). The area is dominated by Hausa, Fulani, Kanuri and the Bede ethnic group with population capacity of $1,000,000$ people; these people depend on this wetland for water supply and other daily activities. According to Idris (2008), the HadejiaNguru wetlands community benefit from various activities that surround the wetlands, such as income generations and provision of food, from the different activities such as agriculture, land grazing, wood for domestic fueling, other wood products, tourism and mechanisms for protection against drought.

Sample Collection: Soils were collected from ten (10) selected sites at $3 \mathrm{~m}$ apart in lateral dimension within the wetlands of Nguru, Yobe State after the rainy season in the month of October, 2016. The soil samples were taken at $0-30 \mathrm{~cm}$ to the surface layer of the soil. Five samples were drawn from each site to give a give a composite sample for the site using a stainless steel soil auger. The composite soil samples were air dried at room temperature and allowed to pass through a 2-mm nylon sieve to remove gravels. The samples were stored in polythene bags prior to soil analysis.

Determination of Soil Physicochemical Parameters: The $\mathrm{pH}$ of soil samples was measured with a soil: water ratio of 1:2 (w/v) using Crison MicropH 2000, $\mathrm{pH}$ meter (Herdeershotet al., 1993). Electric conductivity (EC) Electrical conductivity (EC) was determined in supernatant of 1:5 soil: water mixtures using Digital Conductivity meter model No PT360
(Herdeershot et al., 1993). Soil Particle size distribution was determined by the hydrometer method as described by Bauyocos (1951). Soil organic matter (SOM) was measured using dichromate oxidation (Nelson and Sommers, 1982). The exchange base (Ex-base) was determined by the sum of exchangeable cations (Banerjee et al., 2004).

Determination of Heavy Metals: Soil samples were digested according to Sharidah (1990): 0.5g of soil sample was weighed into $250 \mathrm{~cm}^{3}$ conical flask and moistened with few drops of water to prevent sputtering. $3 \mathrm{~cm}^{3}$ of $30 \% \mathrm{H}_{2} \mathrm{O}_{2}$ was then added and was left to stand for $60 \mathrm{~min}$ until the vigorous reaction ceased. About $75 \mathrm{~cm}^{3}$ of $0.5 \mathrm{~mol} / \mathrm{dm}^{3}$ solution of $\mathrm{HC} 1$ was added and the content heated gently at low heat on the hot plate for $2 \mathrm{~h}$. The digest was allowed to cool, and then filtered into $50 \mathrm{~cm}^{3}$ standard flask. The content was then diluted to $50 \mathrm{~cm}^{3}$ mark and blank digestion without the sample was carried out using the same. Duplicate digestion was carried out for each sample. This method has been widely applied and recognized as informative in environmental metallic investigations where metal fractions associated with carbonate, sulphides, soluble salts organic matter held, Fe-Mn oxides are removed (Awofolu et al., 2005). The solutions were then stored for heavy metal $(\mathrm{Pb}, \mathrm{Fe}, \mathrm{Cd}$ and $\mathrm{Zn}$ ) determination using Atomic Absorption Spectrophotometer (AAS) (Perkin Elmer 400 AAS).

All glassware, polythene tubes and Teflon beakers used in the analyses were pre-cleaned by washing with liquid detergent, rinsed with water and distilleddeionized water, and then soaked in $10 \% \mathrm{HNO}_{3}$ for $24 \mathrm{hrs}$ and rinsed with distilled - deionized water and in such a manner that no contamination occurred (Adnan et al., 2003). Thereafter, the apparatus were oven-dried for $12 \mathrm{hrs}$ at a temperature of $80^{\circ} \mathrm{C}$. All reagents used were of analytical grade, and the instrument working calibration was made by diluting the commercial Scharlau Japan stock solution (1000ppm) standard with distilled-deionized water. Quality assurance and quality control were assessed using duplicates, method blanks and spiking methods using prepared multi-element standard solution of 1 ppm for all the elements presented for the study (1 blank and 1 standard for each 10 sample runs). The recoveries of samples spiked with standards ranged from 935 to $102 \%$.

\section{RESULTS AND DISCUSSION}

Heavy Metal Concentrations: The mean concentrations of $\mathrm{Pb}, \mathrm{Fe}, \mathrm{Cd}$ and $\mathrm{Zn}$ in the wetland agricultural soils are summarized in figures $1-4$. The mean concentrations ranged from 0.53 (Site 4) -84.95 $\mathrm{mg} / \mathrm{kg}$ (Site 3) for Pb, 1.95 (Site 2) - $29.90 \mathrm{mg} / \mathrm{kg}$ (Site 
8) for Fe, 0.13 (Site 5) - $24.95 \mathrm{mg} / \mathrm{kg}$ (Site 7) and 1.63 (Site 3) $-24.95 \mathrm{mg} / \mathrm{kg}$ (Site 7). Generally, the heavy metal concentration profile followed this order: $\mathrm{Pb}>$ $\mathrm{Zn}>\mathrm{Fe}>\mathrm{Cd}$. The correlation analysis showed that $\mathrm{Cd}$ and $\mathrm{Zn}$ are significantly correlated $(\mathrm{p}<0.01)$ as shown in Table 1. This indicates similar sources of these metals in the soil and hence, an increase in $\mathrm{Zn}$ concentration leads to an increase in $\mathrm{Cd}$ concentration. In related studies, Huang et al. (2013) found that the correlation coefficients between $\mathrm{Cd}$ and $\mathrm{Pb}$ and $\mathrm{Zn}$ are 0.465 and 0.395 , respectively, and Xie et al. (2016) reported 0.173 and 0.304 , respectively. In this study, the correlations with $\mathrm{Cd}$ are similar to those reported by Xie et al. (2016).

However, when the levels of these metals in study area were compared with values reported in literature, $\mathrm{Pb}$ across the sites were found to be higher than 0.046 and $0.439 \mathrm{mgkg}^{-1}$, respectively reported by Awofolu et al. (2005), although below $100 \mathrm{mgkg}^{-1}$ permissible levels recommended for agricultural soils (Ewers, 1991).Also, when the levels of these metals in study area were compared with values reported in literature, mean $\mathrm{Cd}$ and $\mathrm{Zn}$ were found to be higher than the values reported by Awofolu et al. (2005), although $\mathrm{Zn}$ is below $300 \mathrm{mgkg}^{-1}$ permissible levels for soils recommended by MAFF (1992), however, Cd concentrations across the sites showed that Sites 7, 9 , 9 and 10 are above the permissible concentration of $3 \mathrm{mgkg}^{-1}$.

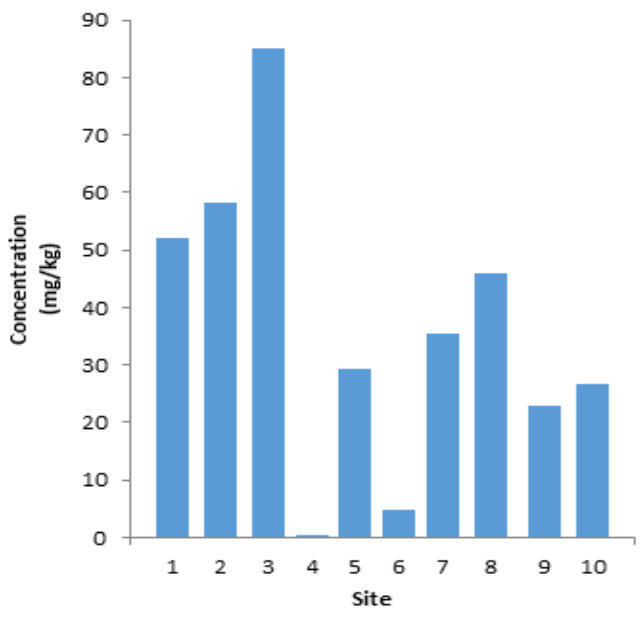

Fig. 1: Concentration of $\mathrm{Pb}$ in the wetland soils

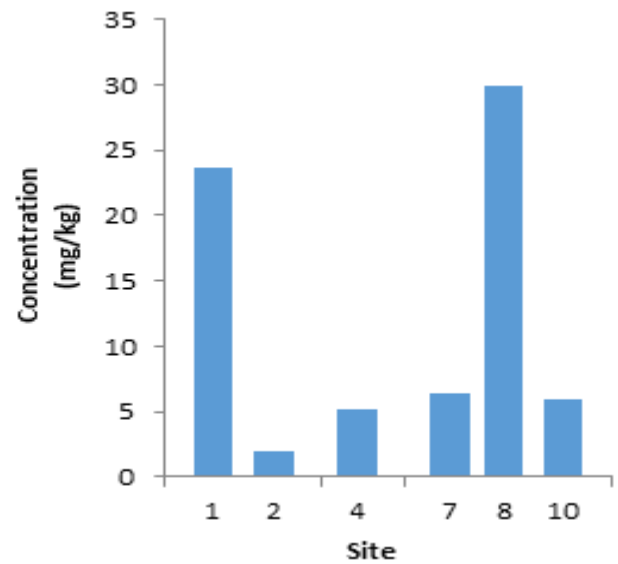

Fig. 2: Concentration of Fe in the wetland soils

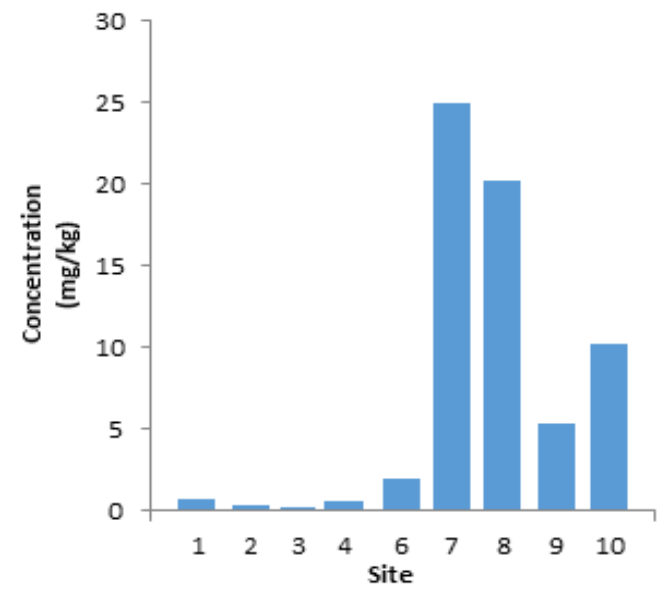

Fig. 3: Concentration of $\mathrm{Cd}$ in the wetland soils

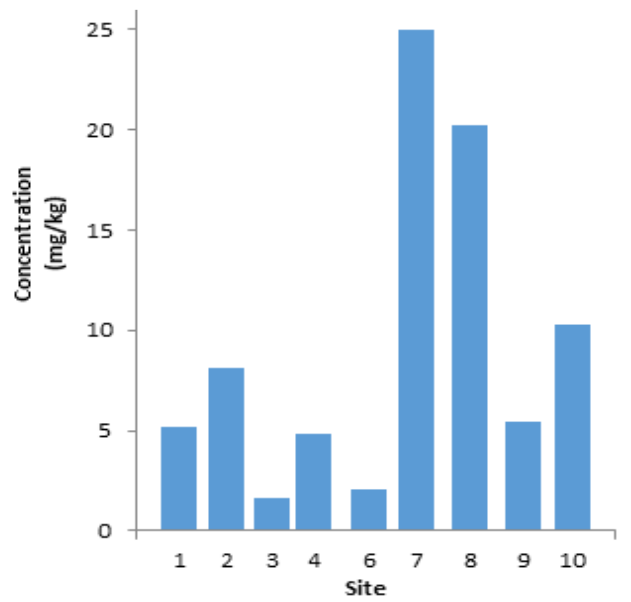

Fig. 4: Concentration of $\mathrm{Zn}$ in the wetland soils

Table 1: Correlation matrix among metals in the wetland soils

\begin{tabular}{lllll}
\hline Parameter & Pb & Fe & Cd & Zn \\
\hline $\mathrm{Pb}$ & 1.000 & \multicolumn{3}{l}{} \\
$\mathrm{Fe}$ & 0.193 & 1.000 & & \\
$\mathrm{Cd}$ & -0.018 & 0.425 & 1.000 & \\
$\mathrm{Zn}$ & 0.065 & 0.488 & $0.954^{* *}$ & 1.000 \\
\hline
\end{tabular}

*. Correlation is significant at the 0.05 level (2-tailed); **. Correlation is significant at the 0.01 level (2-tailed). 
Physicochemical Parameters: The results of all the physicochemical parameters of the $200 \mu \mathrm{m}$ sieved airdried soil samples from the study sites determined are presented in Table 2 . The $\mathrm{pH}_{\mathrm{H} 2 \mathrm{O}}$ and $\mathrm{pH}_{\mathrm{CaCl} 2}$ of the soil samples varied from $7.18-8.85$ and $6.10-7.51$, respectively. The low $\mathrm{pH}$ in $\mathrm{CaCl}_{2}$ compared to $\mathrm{H}_{2} \mathrm{O}$ is due to the hygroscopic nature of $\mathrm{CaCl}_{2}$ thereby increasing the concentration of hydrogen ions. There is no much considerable variation in the $\mathrm{pH}$ values across the sites as shown in Table 2.Electrical conductivity (EC) values ranged from 0.060 to 0.875 $\mathrm{mScm}^{-1}$ and this suggest non-saline growing conditions across the sites. Also, the organic carbon a measure of organic matter in soil varied from $0.139-$ $0.599 \%$. The values are typically low and characteristic of savanna soils because of rapid decomposition of plant and animal residues added to soil (Jones and Wild, 2005). This indicates that the soil organic matter contains humic materials with low complex functional groups, which have the ability to complex metals thereby retaining them in the topsoil (Evans, 1989). The more organic matter is present in soil, the more functional groups available for complexation with the metals, hence, the more the retention (Okunola et al., 2011).The level of available phosphorus (AP) in the soil samples ranged from $1.131-9.428 \mathrm{mg} / 100 \mathrm{~g}$. The phosphorus level in Site 3 is very much greater than the level of the phosphate in other sites. Phosphorus is among the nutrient added to the soils through the application of fertilizer, hence, AP content across the sites showed that Site 3 has high level of phosphorus, this suggest possible input of phosphate from other anthropogenic sources. However, the concentration of AP was higher than 0.3 $-0.6 \mathrm{mg} / 100 \mathrm{~g}$ reported in related study in Nigeria (Oiganji et al., 2015).

\begin{tabular}{|c|c|c|c|c|c|c|c|c|c|c|}
\hline \multirow[t]{2}{*}{ Site } & \multirow{2}{*}{$\mathbf{p H}_{\mathrm{H} 2 \mathrm{O}}$} & \multirow{2}{*}{$\mathbf{p H}_{\mathrm{CaCl} 2}$} & \multirow[t]{2}{*}{$\begin{array}{l}\mathrm{EC} \\
\left(\mathrm{mScm}^{-1}\right)\end{array}$} & \multirow[t]{2}{*}{$\mathrm{OC}(\%)$} & \multirow[t]{2}{*}{$\begin{array}{l}\text { AP } \\
(\mathrm{mg} / \mathbf{1 0 0 g})\end{array}$} & \multicolumn{4}{|c|}{ Exchangeable Base (mg/l) } & \multirow[t]{2}{*}{$\begin{array}{l}\mathrm{TN} \\
(\mathrm{mg} / \mathrm{l})\end{array}$} \\
\hline & & & & & & $\mathbf{C a}$ & $\mathrm{Na}$ & $\mathbf{K}$ & Mg & \\
\hline 1 & 7.36 & 6.94 & 0.480 & 0.339 & 1.886 & 4.70 & 0.765 & 3.285 & 0.349 & 0.105 \\
\hline 2 & 7.59 & 6.94 & 0.165 & 0.319 & 4.526 & 12.80 & 1.814 & 0.780 & 0.849 & 0.105 \\
\hline 3 & 7.70 & 6.10 & 0.195 & 0.439 & 9.428 & 12.10 & 1.883 & 0.440 & 0.766 & 0.105 \\
\hline 4 & 8.85 & 7.51 & 0.875 & 0.599 & 2.263 & 8.77 & 2.416 & 0.485 & 0.566 & 0.140 \\
\hline 5 & 7.21 & 6.93 & 0.100 & 0.459 & 2.639 & 4.44 & 0.808 & 0.225 & 0.333 & 0.105 \\
\hline 6 & 7.38 & 6.79 & 0.060 & 0.299 & 6.034 & 4.36 & 0.877 & 0.230 & 0.333 & 0.105 \\
\hline 7 & 7.25 & 6.61 & 0.200 & 0.239 & 3.771 & 3.88 & 0.791 & 0.125 & 0.299 & 0.105 \\
\hline 8 & 7.18 & 6.41 & 0.500 & 0.339 & 1.131 & 4.36 & 0.688 & 0.215 & 0.349 & 0.105 \\
\hline 9 & 7.84 & 6.70 & 0.125 & 0.139 & 1.886 & 2.47 & 0.971 & 0.100 & 0.316 & 0.070 \\
\hline 10 & 8.48 & 7.28 & 0.395 & 0.179 & 2.639 & 4.93 & 1.075 & 0.300 & 0.349 & 0.070 \\
\hline
\end{tabular}

Table 3: Correlation matrix among physicochemical parameters in the wetland soils

\begin{tabular}{|c|c|c|c|c|c|c|c|c|c|c|}
\hline Parameter & $\mathrm{pH}_{\mathrm{H} 2 \mathrm{O}}$ & $\mathrm{pH}_{\mathrm{caCl} 2}$ & EC & OC & $\mathbf{A P}$ & $\mathrm{Ca}$ & $\mathbf{N a}$ & $\mathbf{K}$ & Mg & TN \\
\hline$\overline{\mathrm{pH}}$ & 1.000 & & & & & & & & & \\
\hline $\mathrm{pH}_{\mathrm{CaCl} 2}$ & $0.651^{*}$ & 1.000 & & & & & & & & \\
\hline $\mathrm{EC}$ & 0.604 & 0.505 & 1.000 & & & & & & & \\
\hline $\mathrm{OC}$ & 0.210 & 0.182 & .0503 & 1.000 & & & & & & \\
\hline AP & -0.090 & -0.510 & -0.440 & 0.157 & 1.000 & & & & & \\
\hline $\mathrm{Ca}$ & 0.254 & -0.068 & 0.106 & 0.486 & 0.596 & 1.000 & & & & \\
\hline $\mathrm{Na}$ & $0.682^{*}$ & 0.274 & 0.428 & 0.598 & 0.366 & $0.817^{* *}$ & 1.000 & & & \\
\hline K & -0.133 & 0.151 & 0.275 & 0.098 & -0.173 & 0.042 & -0.096 & 1.000 & & \\
\hline $\mathrm{Mg}$ & 0.233 & -0.106 & 0.047 & 0.409 & 0.570 & $0.987^{* *}$ & $0.805^{* *}$ & 0.018 & 1.000 & \\
\hline TN & 0.074 & 0.170 & 0.513 & $0.879^{* * *}$ & 0.106 & 0.414 & 0.513 & 0.144 & 0.339 & 1.000 \\
\hline
\end{tabular}

*. Correlation is significant at the 0.05 level (2-tailed); **. Correlation is significant at the 0.01 level (2-tailed).

The exchangeable base of the soil showed ranged of: 2.47 - $12.80 \mathrm{mg} / \mathrm{l}$ for $\mathrm{Ca}, 0.688-2.416 \mathrm{mg} / \mathrm{l}$ for $\mathrm{Na}$, $0.100-3.285 \mathrm{mg} / \mathrm{l}$ for $\mathrm{K}$ and $0.316-0.849 \mathrm{mg} / \mathrm{l}$ for $\mathrm{Mg}$. The content of total nitrogen (TN) in the soil as shown in Tables 2 showed content ranged from 0.070 to $0.140 \mathrm{mg} / \mathrm{l}$. The value in this study is lower than range of $0.2-4.62 \mathrm{mg} / \mathrm{l}$ reported by Oiganji et al. (2015). Correlation analysis amongst soil physicochemical parameters as shown in Table 3 showed the presence of significant positive correlations $(\mathrm{p}<0.05)$ between parameters especially $\mathrm{Na}$ and $\mathrm{pH}_{\mathrm{H} 2 \mathrm{O}}, \mathrm{TN}$ and $\mathrm{OC}, \mathrm{Na}$ and $\mathrm{Ca}, \mathrm{Mg}$ and $\mathrm{Ca}$, and $\mathrm{Na}$ and $\mathrm{Mg}$. Significant positive or negative correlation could therefore indicate a greater influence of one factor on another. Also, as shown in Table 4, the correlation between heavy metals in soils and the soil physicochemical parameters showed positive and negative correlations between heavy metals and the soil physicochemical parameters. Hence, positive correlation between metal concentration and physicochemical parameter could imply a significant effect on the amount of trace metal in the soil, since the mobility and bioavailability of metal present in soils depend on physico-chemical properties of both the metal and the soil (McEldowney et al., 1993). 
Table 4: Correlation matrix between physicochemical parameters and metals in the wetland soils

\begin{tabular}{lllll}
\hline Parameter & $\mathbf{P b}$ & $\mathbf{F e}$ & $\mathbf{C d}$ & $\mathbf{Z n}$ \\
\hline $\mathrm{pH}_{\mathrm{H} 2 \mathrm{O}}$ & -0.381 & -0.274 & -0.264 & -0.225 \\
$\mathrm{pH}_{\mathrm{CaC1} 2}$ & $-0.665^{*}$ & -0.111 & -0.278 & -0.196 \\
$\mathrm{EC}$ & -0.231 & 0.499 & 0.041 & 0.146 \\
$\mathrm{OC}$ & -0.005 & -0.001 & -0.430 & -0.366 \\
$\mathrm{AP}$ & 0.460 & -0.522 & -0.298 & -0.323 \\
$\mathrm{Ca}$ & 0.525 & -0.267 & -0.447 & -0.264 \\
$\mathrm{Na}$ & 0.066 & -0.383 & -0.476 & -0.331 \\
$\mathrm{~K}$ & 0.290 & 0.494 & -0.324 & -0.187 \\
$\mathrm{Mg}$ & 0.536 & -0.290 & -0.459 & -0.272 \\
$\mathrm{TN}$ & -0.101 & 0.118 & -0.184 & -0.061 \\
\hline *. Correlation is significant at the 0.05 level (2-tailed); * \\
Correlation is significant at the 0.01 level (2-tailed).
\end{tabular}

Conclusion: The present study indicates the concentrations of heavy metals in the study areas. Generally, the heavy metals concentration profile showed $\mathrm{Pb}$ as the highest and $\mathrm{Cd}$ as the least across the sites. Also, $\mathrm{Pb}, \mathrm{Zn}$ and $\mathrm{Fe}$ levels are within the permissible levels in the soils. However, $\mathrm{Cd}$ concentrations at some sites are above the permissible level of the metal in soils. The physicochemical parameters determined are generally low with exception of AP, this suggest typical characteristics of savannah soils in Nigeria.

\section{REFERENCES}

Adelana, AO;Oluwatosin,GA; Agunbiade, C; Are, KS; Adeyolanu, OD (2016). Distributions of cadmium and lead in peri-urban wetlands as influenced by soil organic matter, clay fraction, and moisture content. Cogent Food and Agriculture, 2:1159406.

Adnan, M; Feras, A; Qasem, J (2003). Determination of cadmium and lead in different cigarette brands in Jordan. Acta. Chim. Slov. 50: 375 - 381.

Awofolu, OR; Mbolekwa, VM; Fatoki, OS (2005). Levels of trace metals in water and sediment from Tyume River and its effects on an irrigated farmland. Water S. A., 31(1): 87 - 94

Banerjee, SS; Joshi, MV; Jayaram, RV (2004). Removal of $\mathrm{Cr}$ (VI) and $\mathrm{Hg}$ (II) from aqueous solutions using fly ash and impregnated fly ash. Sep. Sci. Technol. 39(7): 1611-1629.

Binns, JA; Maconachie, RA; Tanko, AI (2003). Water, land and health in urban and peri-urban food production: The case of Kano, Nigeria. Land Degrad. Develop. 14, 431-444.

Bouyocos, GH (1951). Determination, of particle sizes. Soil Agron. J. 43: 434-438.
Evans, LJ (1989). Chemistry of Metal Retention by Soils. Environ. Sci.Technol.23: 1046-1056.

Ewers, U (1991). Standard Guidelines and Legistative Regulations concerning metals and their compounds. In: Metals and their compounds in the environment: Occurrence, Analysis and Biological Relevance. Merian E. (Ed.) Weinheim VCH no: 458 - 468.

Herdershot, W; Lalande, H; Duquette, M (1993). Soil reaction and exchangeable acidity in: carter M.R (Ed). Soil sampling and methods of analysis for Canadian society of soil science Lewis. Boca Ratio, FL. p. 141 - 145.

Huang, LL; Pu, XM; Pan, JF; Wang, B (2013). Heavy metal pollution status in surface sediments of Swan Lake lagoon and Rongcheng Bay in the northern Yellow Sea. Chemosphere, 93(9): 19571964.

Idris M (2008). Damming Nigeria's Wetlands People: Communities Work Together to Restore Lives and Livelihoods. International Rivers.

Ita, RE; Anwana, ED (2017). Geochemical Assessment of Heavy Metal Contamination in rural and urban wetlands in Akwa Ibom State, Nigeria. New York Sc. J. 10(11): 43-51.

Kar, D (2013). Wetlands and Lakes of the World, New Delhi: Springer, India.

MAFF (Ministry of Agriculture, Fisheries and Food Welch Office Agriculture Department). (1992). Code of good agriculture practice for the protection of soil. Draft Consultation Document, MAFF London.

May, PA; Edwards, GS (2001). Comparison of heavy metal accumulation in a natural wetland and constructed wetlands receiving acid mine drainage. Eco. Engineer. 16: 487-500.

Mbabazi, J; Bakyayita, G; Wasswa, J; Muwanga, A; Twinomuhwezi, H; Kwetegyeka, J (2010). Variations in the contents of heavy metals in arable soils of a major urban wetland inlet drainage system of Lake Victoria, Uganda. Lakes \& reservoirs: Res. Manage. 15: 89-99.

McEldowney, S; Hardman DJ; Waite, S (1993). Pollution, Ecology, and Biotreatment. Longman Scientific and Technical, p. 6-8, 251-258. 
Mitsch, WJ; Gosselink, JG (2000). Wetlands. New York: John Wiley and Sons, p. 920.

Nelson, DW; Sommers, LE (1982). Total carbon, organic carbon, and organic matter.In: Page, A.L., Miller, R.H., Keeney, D.R. (Eds.), Methods of Soil Analysis. AmericanSociety of Agronomy, Wisconsin, p. 539 - 579.

Nwankwoala, H (2012). Case studies on coastal wetlands and water resources in Nigeria. European Journal of Sustainable Development, 1: 113-126.

Oiganji, E Igbadun, HE; Ahmed, A; Oliver, UE (2015). Implication of Bakolori Dam Irrigation Activities on Its Physical Resources. Afr. J. Agric. Res. 10, 690 - 696.

Okunola, OJ; Uzairu, A; Gimba, CE; Kagbu, JA (2011). Metal Inter-Relationship and Its Mobility in Sample Collected along Roadside Corridors of Kano Metropolis, Nigeria. Res. J. Environ. Toxicol. 5: 336-347.

Okusami, TA; Rust, RH (1992). Occurrence, characteristics and classification of some hydromorphic soils from south Nigeria. In J. M. Kimble (Ed.), Characterization, classification and utilization of wet soils (p. 185-197). USDA, Soil Conservation Service: Proceedings VIII ISCOM.
Olalekan, EI.; Abimbola, LM; Saheed, M; Damilola, OA (2014). Wetland Resources of Nigeria: Case Study of the Hadejia-Nguru Wetlands. Poultry Fish Wildlife Sci. 2: 123.

Rafferty, JP (2011). Lakes and Wetlands, the Rosen Publishing Group.

Ramsar, C (1994). Convention on Wetlands of International Importance Especially as Waterfowl Habitat, United Nations Educational, Scientific and Cultural Organization (UNESCO): Paris, France.

Shriadah, MMA (1999). Heavy metals in mangrove sediments of the United Arab Emirates Shoreline (Arabian Gulf). Water. Soil Pollut. 116: 523 534.

Verones, F; Pfister, S; Hellweg. S (2013). Quantifying area changes of internationally important wetlands due to water consumption in LCA. Environ. Sci. Technol. 47: 9799-9807.

Xie, Z; Zhang, H; Zhao, X; Du, Z; Xiang, L; Wang, W (2016). Assessment of Heavy Metal Contamination and Wetland Management in a Newly Created Coastal Natural Reserve, China. J. Coastal Res. 32(2):374-386. 